\title{
Tough talk on surrogate birth
}

Is it wholly wrong that married couples unable to conceive children naturally should pay others to perform that service? Mistakenly, Britain is behaving as if there were no doubts.

IT was always on the cards that the British government, by its failure to legislate more quickly on the recommendations of the Warnock committee, would allow a muddle to develop. It seems to have a useful ally in that cause in the British Parliament. The most urgent need is that the position of those wishing to make observations of living embryos should be clarified; the Warnock committee advocated experiments under licence with cmbryos up to 14 days, whereafter any experiment would become the cause of a criminal prosecution. It would be good to think that the government has recognized the unwisdom of that proposal, and that it plans to legislate for licensing, coupled with supervision by independent committees, allowing researchers more flexibility, but there is no way of telling. Meanwhile, research limps along uncertainly, under the non-statutory supervision of a committee established by the Medical Research Council and the Royal College of Obstetricians and Gynaecologists - and the Houses of Parliament chip away piecemeal at what should be the government's responsibility. The dangers of this approach are well illustrated by the fate of last year's instant legislation, begun in the House of Commons, when the sale of surrogacy services became an offence. One consequence appears to have been that British couples who are infertile are seeking the service overseas, which the House of Lords will this week attempt to ban by law, making it illegal for agencies in Britain to offer to provide such services even with the help of surrogate mothers elsewhere. Presumably the result will be that the agencies concerned will operate offshore.

This is the inevitable result of attempts to prevent wellintentioned people from using what seems to them a natural way of meeting a natural need. Procreative instincts have an adaptive significance for all species and, while they may become a nuisance in long-lived human societies, cannot be repressed by legislation. Moreover, it is natural that couples should prefer genetically related to unrelated children: Dawkins's concept of the selfish gene, not to mention a great deal of sociobiology, refers. The Warnock committee, after eighteen months of careful study, was itself divided on the issue; the majority would have made surrogacy a criminal offence when money changes hands, partly by analogy with the law covering the adoption of children in Britain. But a minority wisely argued that circumstances might arise in which paid surrogacy is justified. (It seems to be common ground that the willingness of some women to bear children for close relatives, another illustration of the selfishness of genes, should not be prevented by law if no money changes hands.) What, for example, if a woman is infertile as a result of a hysterectomy? This is one of the questions raised last weekend by Dr Robert Edwards and Mr Patrick Steptoe, the pioneers of in vitro fertilization in Britain. It is hard to deny their case for surrogacy, ideally based on a fertilized egg from the infertile woman, but the British Parliament would even stop that.

The weakness in the British Parliament's position on surrogacy is that it confuses two quite unrelated emotional issues. Some people believe simply that unfamiliar practices are wicked, and should be stopped. This is, after all, the Parliament that required that men with red flags should walk in front of the early motorcars. The other cause for anxiety, legitimate as it happens, is that surrogacy might become a vehicle for the exploitation of those concerned, either surrogate mothers or the putative genetic parents. So what the House of Lords should have been doing this week, and what the House of Commons will in due course have to decide, is how to protect the vulnerable parties to these transactions without denying remedies to those determined to have children.

The best solution, for which there is already a good working model, is that arrangements for surrogacy should be made not by commercial agencies but by corporations with the legal status of charities (which, in Britain, is what adoption societies are). But since it is wrong to hazard the lives of women by childbirth on behalf of others, it is quite wrong to insist that the surrogate mothers should not be paid. On the contrary, they should be insured financially against risk, while compensation for the considerable time and trouble is the opposite of outrageous. Further, all those concerned in a surrogacy arrangement should have the benefit of independent counselling, of a kind unlikely to be fully convincing if provided by an agency with a profit to make. That constructive course, not futile repression, is the wise course to follow.

\section{Future for the birds}

\section{The future of the US shuttle is still in doubt, but the causes of what went wrong are clear.}

THE reappointment of Dr James C. Fletcher as administrator of the US National Aeronautics and Space Administration (NASA) is one step towards the agency's rehabilitation (see p.100), but there is a long way to go. Although the technical cause of the failure of Challenger two months ago has not been finally pinpointed by the US President's commission of inquiry, it stands out a mile that the fault within the agency was simply the failure of bad news about the risk of rocket failure to travel upwards to those most in need of it, the people responsible for deciding how quickly to push ahead with the shuttle programme. No doubt before the commission's inquiry is over, it will become clear that the chief inhibition was the familiar phenomenon that the bearers of bad news usually win less than meagre credit. The shuttle pilots were probably right to have complained, earlier this week, that the shuttle should have been grounded at least since last summer.

Dr Fletcher's immediate problem is technical, how to get the shuttle safely off the ground again. He will have to say quite openly that he will not be able to do that on a shoestring, which may make him the bearer of bad news in the year when the Gramm-Rudman act comes into effect. He will also need to develop, or otherwise procure, an unmanned satellite launcher that can be used for the routine business of putting routine satellites into routine orbits, when it is pointless to risk people's lives. Meanwhile, the ambitious scheme for building a permanent space station should be postponed at least until the shuttle is made safe. But further ahead, he must find a way of encouraging constructive fault-finding within the agency. 